JBSED

3,1

86

Received 16 July 2021

Revised 23 August 2021 27 January 2022

Accepted 11 February 2022

\section{Determinants of the intellectual capital efficiency of listed banks in Nigeria: a DEA approach}

\author{
Aminat Olayinka Olohunlana, Anthonia Taye Odeleye and \\ Wakeel Atanda Isola \\ Department of Economics, University of Lagos, Lagos, Nigeria
}

\begin{abstract}
Purpose - This study empirically investigates the level of intellectual capital efficiency amongst the listed commercial banks in Nigeria and the factors influencing its efficient utilisation.

Design/methodology/approach - The paper employs the data envelopment analysis (DEA) to determine intellectual capital efficiency for the listed banks in Nigeria using data obtained from their annual financial reports from 2013 to 2019 . After obtaining the efficiency scores, the Tobit regression technique was used to analyse the impact of firm-specific factors on intellectual capital efficiency.

Findings - The study found that only $8.33 \%$ of the sampled Nigerian commercial banks are at optimum capacity in utilising their intellectual capital, while $91.67 \%$ are inefficient. It also finds that bank size and directors' shareholdings positively impact intellectual capital efficiency, while market and ownership concentration debar the attainment of optimum intellectual capital efficiency.

Research limitations/implications - This study contributes to very scare literature on intellectual capital efficiency measurements by using the non-parametric analysis (DEA) to measure intellectual capital efficiency for listed banks in Nigeria.

Practical implications - This study showcases the importance of measuring intellectual capital efficiency amongst listed banks in Nigeria. It provides more information to the regulators and stakeholders on the need to enforce the disclosure of the value created from intellectual capital investment.

Originality/value - This study contributes to the scarce literature on measuring intellectual capital efficiency using a non-parametric analysis (DEA). It also provides new insights into the factors that influence intellectual capital efficiency amongst listed commercial banks in Nigeria.
\end{abstract}

Keywords Intellectual capital efficiency, Data envelopment analysis, Listed banks, Nigeria

Paper type Research paper

\section{Introduction}

In the last 2 decades, a drastic transition of economies has emerged, from a traditional-driven approach to a more knowledge-intensive driven approach (Ali and Anwar, 2021; Vidyarthi, 2018). The change is in line with the catch-up of economies with Industrial Revolution 4.0 with particular insights into competitiveness and value creation (Adeosun et al., 2021; Ofori-Sasu et al., 2019). Thereafter, knowledge became a vital tool for achieving a sustained competitive advantage for the economies and firms domiciled in such economies (Nitkiewicz et al., 2014). In this modern age, this composition of knowledgeable assets in a firm has moved away from mere acquisition of highly skilled employees to more encompassing components such as structural capability development, trade secret, patent and trademarks, customer retentiveness, social responsibilities and a host of other intangible assets (Isola et al., 2019; Sardo and Serrasqueiro, 2019). This intangible component within the firm is what is referred

(C) Aminat Olayinka Olohunlana, Anthonia Taye Odeleye and Wakeel Atanda Isola. Published in Journal of Business and Socio-economic Development. Published by Emerald Publishing Limited. This article is published under the Creative Commons Attribution (CC BY 4.0) licence. Anyone may reproduce, distribute, translate and create derivative works of this article (for both commercial and non-commercial purposes), subject to full attribution to the original publication and authors. The full terms of this licence may be seen at http://creativecommons.org/licences/by/4.0/legalcode. 
to as intellectual capital. Intellectual capital was first mentioned by Galbraith (1969) and later popularised by Stewart (1997). The concept has thereafter received scholarly attention in the firm performance literature due to its value relevance on firm competitiveness, growth and sustainability (Isola et al., 2020; Hamdan, 2018).

Due to the sustainability goal of firms amidst increasing competition, corporate drivers are becoming more enlightened on the need to develop their intellectual capital or assets (Buallay et al., 2020; Kweh et al., 2021). Intellectual capital improves and sustains rare and imitable comparative advantages (Sardo and Serrasqueiro, 2019; Xu et al., 2021; Wang et al., 2014). Furthermore, it builds organisational competencies as well as drives value addition. Overall, intellectual capital improves firms' productivity, growth and sustainability (Kamukama, 2013). Although intellectual capital development poses significant advantages to firms with massive investment in it, measuring its efficiency is essential to their survival and sustainability. Measuring intellectual capital efficiency assists the corporate drivers in making decisions on the optimal utilisation resources for performance improvement (Jamsidy et al., 2014).

Despite the importance of intellectual capital to firm performance, the complexity in measuring its efficiency becomes elusive. Ratio analysis is one of the most exhaustive measures of intellectual capital efficiency adopted in the literature (Anifowose et al., 2018; Isola et al., 2020; Kweh et al., 2021). The ratio analysis measure of intellectual capital uses the ratio of human, structural and relational intellectual capital to the firms' value-added. The ratio analysis as a measure of efficiency may not be an appropriate measure because of its partial and subjective nature. Hence, the ratio analysis approach of measuring efficiency may provide misleading findings. In light of this, the measure of intellectual capital efficiency through the data envelopment approach (DEA) may be more appropriate. DEA, which is a non-parametric measurement approach, can conveniently extend the ratio analysis to accommodate the interactions between multiple inputs and outputs (Feroz et al., 2003).

In developed countries, numerous studies (Jamsidy et al., 2014; Mohd-Ariff et al., 2016; Sardo and Serrasqueiro, 2019) have examined intellectual capital implications on firm performance, and their findings pointed that intellectual capital, as a strategic resource, aids firms' competitiveness and performance. However, in the developing countries, there has been divisive pieces of evidence on the few strands of studies on the link between intellectual capital efficiency and firm performance (Anifowose et al., 2018; Kweh et al., 2013; Olunifesi and Bontis, 2012). For instance, Anifowose et al. (2018) found that intellectual capital efficiency positively influences firms' performance for firms in Nigeria. Olunifesi and Bontis (2012), on the other hand, observed that intellectual capital management does not have any influence on the performance of telecommunication companies.

Amidst mixed findings on the link between intellectual capital and firm performance, it is imperative to understand the factors that enhance firms' efficient utilisation of intellectual capital. This is because the factors underlining intellectual capital efficiency may influence its impact on performance. Although the link between intellectual capital and performance has been well established in the literature, very rare studies are found on the critical examination of the factors that influenced intellectual capital efficiency. The factors that determine intellectual capital efficiency could significantly contribute to the discrepancies in the outcomes of studies on the link between intellectual capital and firm performance. Secondly, the use of DEA as a measure of efficiency has not been widely explored in the intellectual capital efficiency literature. Hence, this study intends to measure intellectual capital efficiency through the DEA approach. It further un-riddles the determinants of the intellectual capital efficiency of banks in Nigeria. Hence, this study contributes to the literature by being the first to measure the degree of efficient utilisation of intellectual capital for commercial banks in Nigeria. Secondly, it contributes to the scare literature on the factors that influence intellectual capital efficiency of listed commercial banks in Nigeria. 
JBSED 3,1

The rest of the study is organised as follows. Section 2 presents a concise theoretical and empirical review of existing studies. Section 3 delves on the methodological and analytic framework of the study by justifying the use of DEA for estimating intellectual capital efficiency and Tobit regression analysis for examining its causal factors. Section 4 presents the empirical findings, and the key outcomes are as follows. One, findings emanating from the non-parametric analysis insinuate that listed banks in Nigeria are not technically efficient in utilising intellectual capital. Two, the bank size and director's shareholding strongly influence the banks' intellectual capital efficiency. Three, ownership and market concentration exhibit detrimental effects on intellectual capital efficiency. Arising from the highlighted empirical discoveries, Section 5 highlights the study's concluding implications and future research agenda on intellectual capital efficiency.

\section{Review of literature}

The human theory believes that firm employees are crucial assets and emphasises the need to develop them for improved productivity, growth and survival (Tran and Vo, 2020). However, the theory fails to consider the role of structural processes, procedures and databases as critical components that enhance the performances of human capital. Furthermore, it fails to explain the influence of the social and customer interrelationship with the organisation as another critical element to the productivity and growth of the organisation. An improvement in human capital theory was explained by the organisational learning theories, resourcebased theory and resource-dependency theory. The resource-based theory lays particular importance on the development of internal resources for optimal firm performances (Anifowose et al., 2018; Bayraktaroglu et al., 2019; Isola et al., 2020). The internal resources are both the human and structural capabilities in the organisation. Although the theory lays credence to efficient utilisation of resources within an organisation, it fails to point to the significance of the firms' relationship with external resources such as the customers, regulators and society (Cenciarelli et al., 2018). The external resources, when built up, create intangible assets in terms of social or relational capital to the firms. On the other hand, the resource-dependency theory links the performances of firms to the intangible resources accumulated through the firm's external relations.

Empirically, studies on the efficient utilisation of the company's intangible resources have continued to attract increasing attention due to its importance to the growth and survival of firms. The findings of the studies are therefore mixed. For instance, Vidyarthi (2018) assessed the impact of intellectual capital on banks' performances in India. Using the DEA and Tobit regression, the study found that intellectual capital exhibited a positive and significant impact on banks' technical, allocative and scale efficiencies in India. Similarly, Kweh et al. (2013) studied the importance of intellectual capital on the operational efficiency of non-life insurance firms in China. The study employed the DEA and the ordinary least squares (OLS) regression for its analysis for the period between 2006 and 2010. It found that intellectual capital contributes significantly to the firms' operational efficiency. Wu et al. (2007) did a cross-sectional examination of the influence of intellectual capital on firms' performances in Taiwan for the year 2006. It was, however, discovered that only half of the firms in Taiwan are technically efficient during the period under examination. Venugopal and Nambi (2018) conducted a case study analysis of the impact of intellectual capital efficiency on the performance of a particular firm for twenty years. The study revealed that the firm was at full intellectual capital efficiency for only one-third of the period under investigation. On the contrary, Nitkiewicz et al. (2014) assessed the impact of intellectual capital across regions in Poland. The study posits that intellectual capital efficiency is not evenly distributed across the region.

Extensive empirical analysis on the implications of intellectual capital on firm performance was also explored in the developing countries, albeit with mixed outcome. 
Alhassan and Asare (2016) conducted an empirical examination on the impact of intellectual capital on technical efficiency and productivity of commercial banks in Ghana. The study found that intellectual capital has positive impacts on banks technical efficiency and productivity in Ghana. Similarly, Onyekwelu et al. (2017) discovered that intellectual capital has a strong and positive implications of banks' performance in Nigeria. However, Mohammed and Irbo (2018) documented contrary evidence on the link between intellectual capital and performances of banks in Ethiopia. The study found that intellectual capital is weakly correlated to the returns on assets for the commercial banks in Ethiopia.

More so, Anifowose et al. (2018) enquired on the effects of intellectual capital efficiency on economic value added of firms in Nigeria. The study which employed the system generalised methods of moment (SYSGMM) found that intellectual capital has a positive and significant relationship on economic value added and future cash flows of firms in Nigeria. While Isola et al. (2019) could not ascertain the significance of intellectual capital on the listed firms in Nigeria, Olunifesi and Bontis (2012) noted that intellectual capital is weakly correlated to performances of firms in the Nigerian telecommunication industry.

Based on the different outcomes of the impact of intellectual capital on performances, scholars enquired into the factors that determine the efficient utilisation of intellectual capital. For instance, Meressa (2016) examined the determinants of the intellectual capital performance of banks in Ethiopia. The study that adopted the fixed effect regression analysis found that bank profitability and investment in ICT are the main determinants of intellectual capital efficiency. Kweh et al. (2013) examined the level and determinants of the intellectual capital of software companies in Malaysia. The study adopted DEA to analyse the IC efficiency levels of the companies, and later employed the OLS and Tobit regression to analyse the factors that determine the intellectual efficiency of the firms. The findings revealed that the firms are not efficient in intellectual capital utilisation. It further revealed that sales growth significantly improves the efficient utilisation of intellectual capital of the software companies. It was, however, noted that there appears to be a dearth of literature on the determinants of intellectual capital efficiency in Nigeria. This study, therefore, assesses the efficient utilisation of the intellectual capital of banks in Nigeria.

\section{Data and method of analysis}

The study employed longitudinal data to examine the determinants of intellectual capital efficiency of listed commercial banks in Nigeria. The input, output and other determining variables were obtained from the annual reports of listed commercial banks as published in the Nigerian Stock Exchange (NSE). The data span from the year 2013 through 2019. The study focuses on the listed commercial banks in Nigeria. The number of the listed banks in Nigeria stood at 23 as at the end of the 2019 financial year. The study selected only 12 listed commercial banks based on the following exclusion criteria. First, listed commercial banks that reported a negative return on assets during the study period were excluded. This is because the estimation technique for the efficiency analysis does not accommodate negative values. Second, listed banks with regional licenses are also excluded from the analysis based on the inconsistency in their financial reporting. Lastly, listed banks with 5-year data gap and those with non-availability of key variables were also excluded from the analysis. After all the exclusion criteria are carefully considered, the study considered twelve listed commercial banks as its sample size.

\subsection{Data envelopment analysis: a non-parametric efficiency measurement approach}

Data envelopment analysis (DEA) is an efficiency measurement technique based on the linear programming composite tool for the comparison of multiple inputs and outputs of firms (otherwise known as decision-making units (DMU)). DEA allows measuring efficiency and 
JBSED 3,1

setting a benchmark for x-efficiency firms (Charnes et al., 1978). It has been widely adopted for measuring efficiency because it allows for a multiplicity of inputs and outputs rather than the unidimensional financial ratios. The DEA is suitable for efficiency measures of the interaction of multiple indicators such as the intellectual capital components. DEA specifically projects the x-inefficient DMUs and their position on the production possibility frontiers, where inefficiency is measured in terms of input or output orientation (Kuo et al., 2020). The input orientation centres on the measures to reduce production inputs, while output remains constant. On the other hand, the output orientation concerns the maximum variation of output when all the productive input is constant over time (Banker et al., 2021).

In examining the efficiency levels of intellectual capital, the corporate drivers are saddled with the responsibility of deciding on the limit of intellectual capital investments that the DMUs are willing to undertake. Hence, the study applies the output orientation approach. Another cogent criterion for employing the DEA is the possibility of choosing the scale of returns of the DMUs. DEA model allows for the flexibility of choice of the returns to scale. The basic and foremost CCR (Charnes et al., 1978) model assumes that the DMUs are operating at a constant return to scale, but this assertion was criticised by Banker et al. (2021) with the model developed to accommodate the variable returns to scale since DMUs are not operating on the same level of scale returns. Based on the above, the study applies the Banker, Charnes and Cooper (BCC) model because it overcomes the challenges of constant returns to scale (Charnes et al., 1978).

Against this background, the study assumes $\rho$ number of DMUs with $\alpha$ series of output and $\beta$ different inputs. Therefore, $\mathrm{DMU}_{t}(t=1,2,3 \ldots \ldots \ldots f)$ consumes $y_{i t}(i=1,2, \ldots \ldots \ldots$ $\ldots g)$ of input $\beta$ and produces $\boldsymbol{\Psi}_{x t}(x=1,2, \ldots \ldots h)$ of output $\alpha$. The model for the evaluation of intellectual capital technical efficiency of the banks (DMUs) stems on the works of Kweh et al. (2013), and it is expressed as follows:

$$
\text { Maximise } \theta_{o}=\sum_{\alpha=1}^{s} \omega_{r}, \Psi_{x o} \omega_{o}
$$

Subject to:

$$
\begin{gathered}
\sum_{\alpha=1}^{\beta} v_{i} \mathrm{y}_{i t}=1 \\
v_{i} \geq 0, \omega_{r} \geq 0, \omega_{o} \text { free in sign }
\end{gathered}
$$

where $\omega_{r}$ and $v_{i}$ are the output and input weights, $\omega_{o}$ is the equality condition and the efficiency parameter equals 1 .

\subsection{Description of variables}

Following Kweh et al. (2013) and Lu et al. (2010), intellectual capital efficiency is estimated using the DEA model. The VAIC model of Pulic (2000), the most widely acceptable measure of intellectual capital, shall be adopted for this study. The model has experienced wide acceptability due to its objectivity in data collection and its ability to enhance intra- and interindustrial comparison of firms. Despite that, the model does not proffer any information on how other factors determine IC efficiency. In light of this, the study still maintains the components as introduced by Pulic (2000) but further stratifies it into input and output variables to examine the efficiency levels of firms' intellectual capital. Intellectual capital is made up of the human capital, structural capital and the capital employed; however, Pulic (2000) expresses the IC components as a ratio of firms' value-added. Hence, the components are derived as a ratio of the value-added sum in an organisation. 
The formula is expressed as:

$$
\begin{gathered}
\mathrm{HCE}=\text { value added / human capital } \\
\mathrm{SCE}=\text { value }- \text { added } / \text { structural capital } \\
\mathrm{CCE}=\text { value }- \text { added / Equity capital }
\end{gathered}
$$

Intellectual capital efficiency

where HCE + SCE is the intellectual capital components (ICE), while CCE is the financial/ physical capital. The summation of the ICE and CCE is what is termed the value-added intellectual capital. Value-added is the difference between the operating revenue and the operating expenses (employee cost excluded). Human capital is proxy as the cost of salaries and wages; structural capital is the difference between value-added and employee cost. Equity capital is the closing value of shareholders fund for a particular year. The DEA model assumes the utilisation of particular inputs for a desired maximum output. In the estimation of value-added intellectual efficiency, the components of intellectual capital in terms of human, structural and equity capital shall be the input, while returns of equity and assets are the banks outputs.

\subsection{Model specification}

Following the need to examine the levels of intellectual capital of commercial banks in Nigeria as the factors that influence its efficient utilisation, a two-stage procedure involving DEA and regression analysis shall be employed. The explanatory variable shall be the VRS technical efficiency scores obtained from DEA, while the explained variables are firm size, market concentration, ownership and directors' shareholdings. The model for the second stage regression analysis is expressed as follows:

$$
E F F_{\text {scoreit }}=\gamma_{0}+\gamma_{1} \text { Firm }_{i t}+\gamma_{1} \text { Herf }_{i t}+\gamma_{1} \text { Ownc }_{i t}+\gamma_{1} \text { Dshare }_{i t}+\varepsilon_{i t}
$$

where $E F F_{\text {scoreit }}$ is the variable returns to scale efficiency score obtained through the outputoriented BCC model. Firm $i t$ is the size of bank expressed as the natural log of the total assets, while $\operatorname{Herf}_{i t}$ is measures the concentration of the bank within the industry. It suggests that the position of the banks may influence their level of competitiveness. Ownc it is the ratio of individual ownership to institutional ownership. Dshare $i t$ is the percentage of the capital owned by the board of directors.

\section{Empirical results}

Table 1 present the descriptive behaviour of the input and output factors employed in the DEA analysis. The factor outputs are performance measures, while the factor input components of intellectual capital are the inputs. The table shows that human capital exhibits a more significant influence than structural and equity capital in terms of creating values for the firms within the period examined. Moreover, the bank has better utilisation of the

\begin{tabular}{lcccc}
\hline Variable description & Mean value & Std. dev. & Maximum & Minimum \\
\hline Return on assets & 0.02 & 0.02 & 0.08 & 0.00 \\
Return on equity & 0.15 & 0.16 & 1.19 & 0.01 \\
Human capital efficiency & 3.35 & 1.79 & 9.49 & 1.20 \\
Structural capital efficiency & 0.63 & 0.17 & 0.89 & 0.16 \\
Equity capital efficiency & 0.38 & 0.11 & 0.62 & 0.16
\end{tabular}

Source(s): Authors computation, 2021

Table 1. 
JBSED 3,1

92

shareholders' fund than its assets. This affirms that banks create more value through their intangible resources than their physical assets.

\subsection{Efficiency analysis of banks in Nigeria}

The efficiency scores of the selected commercial banks in Nigeria are presented in Table 2. The mean technical efficiency of the banks is $58.5 \%$ for the period examined. This indicated that the banks in Nigeria are not fully efficient. The dynamic utilisation of resources amongst the banks suggests a higher efficiency level than the constant returns to scale efficiency measure. This is reflected in the 85.6 and $62.8 \%$ overall mean values of the variable returns to scale and the scale efficiency, respectively. Overall, it was suggestive from the result that the corporate drivers of the banks are inefficient in the utilisation of intellectual capital due to technical and allocative problems, as only $8.33 \%$ of the firms attained optimum technical efficiency. Technical in the sense that the managers cannot extensively deploy state-of-theart technological and innovative tools to drive competitiveness.

The allocative deficiencies may arise as a result of issues relating to conflict resolutions. However, the banks should improve their intellectual capital efficiencies to improve competitiveness and value creation. The result aligns with the works of Kweh et al. (2013), who confirm that only $50 \%$ of the insurance firms in China are fully efficient in utilising their intellectual capital.

\subsection{Determinants of intellectual capital efficiency in Nigeria banks}

In determining the factors influencing the intellectual capital efficiency of commercial banks in Nigeria, it is required to establish that the covariates are not strongly correlated to reduce the problems of multicollinearity. Table 3 presents a correlation analysis of the determining factors of the intellectual capital efficiency of listed banks in Nigeria. The correlation coefficient shows that all the confounding covariates are not perfectly correlated with intellectual capital efficiency. By implication, the model specified is free from running into spurious regression output because the fear of multicollinearity is allayed.

However, the ownership concentration and director shareholding positively influence the efficient utilisation of intellectual capital. From the analysis, there is no incidence of multicollinearity. The result from the OLS regression and Tobit regression is presented in

Table 2.

Efficiency scores of selected commercial banks in Nigeria

\begin{tabular}{|c|c|c|c|}
\hline Name of banks & $\begin{array}{l}\text { CRS } \\
\text { Technical efficiency }\end{array}$ & $\begin{array}{l}\text { VRS } \\
\text { Technical efficiency }\end{array}$ & Scale efficiency \\
\hline Access Bank & 0.643 & 0.799 & 0.823 \\
\hline Diamond Bank & 0.319 & 0.913 & 0.359 \\
\hline Fidelity Bank & 0.494 & 0.894 & 0.553 \\
\hline First Bank of Nigeria & 0.397 & 0.625 & 0.618 \\
\hline Guarantee Trust bank & 1.000 & 1.000 & 1.000 \\
\hline Skye Bank & 0.452 & 0.699 & 0.646 \\
\hline Stanbic IBTC Bank & 0.466 & 0.751 & 0.558 \\
\hline Sterling Bank & 0.725 & 0.970 & 0.739 \\
\hline United Bank of Africa & 0.602 & 0.748 & 0.796 \\
\hline Unity Bank & 0.568 & 0.988 & 0.641 \\
\hline Wema Bank & 0.464 & 0.923 & 0.514 \\
\hline Zenith Bank & 0.893 & 0.958 & 0.935 \\
\hline Mean efficiencies & 0.585 & 0.856 & 0.682 \\
\hline \multicolumn{4}{|c|}{ on from DEAP version } \\
\hline
\end{tabular}


Table 4. The result shows that the bank size has a positive and robust contributory effect in influencing intellectual capital efficiency.

This may be attributed to the fact that large banks are more profitable than smaller banks; hence, they invest more in their intellectual capital stock, thus creating increased efficiency. This study contradicts the results of Kweh et al. (2013), which noted that firm size is not a significant determinant of the intellectual capital efficiency of insurance firms in China. The findings further reveal that director shareholding is another critical determinant of the intellectual capital efficiency of banks in Nigeria. The result is consistent with the study's outcome by Siti et al. (2012), which indicated that intellectual capital performance depends on the directors' shareholding in Malaysia.

The study further shows that market concentration has negative implications on the intellectual capital efficiency of banks in Nigeria. This may be attributed to the fact that market concentration may dissuade firm drivers from concentrating on investments in intellectual capital. This finding negates the position of Choi (2019), who could not find any significant link between market concentration and firm performance. Finally, the result also revealed that the ownership concentration negatively influences the efficient utilisation of intellectual capital resources in the banking sector. The finding implies that ownership concentration may reduce the efficiency of firm resource utilisation when decisions on investment and productive activities are hijacked from the managers by the business owners. This study outcome contrasts the position of Nashier and Gupta (2020) who posit that ownership concentrations reduce agency cost, thus having a considerable influence on firm performance through efficient resource utilisation.

\section{Conclusion}

This study examines the level of intellectual capital efficiency and its determinants in the Nigerian banking industry. Using annual data obtained from the audited annual financial reports of the banks between 2013 and 2019, the study found that majority of the banks in Nigeria are inefficient in utilising their intellectual capital. This indicated that most of the banks
Intellectual capital efficiency
Description of variables

VRS technical efficiency

Firm size

Herfindahl index

Ownership concentration

Director's shareholding

Source(s): Authors' computation, 2021

\section{(a)}

$\begin{array}{lr}\text { (a) } & 1.00 \\ \text { (b) } & -0.26 \\ \text { (c) } & -0.26 \\ \text { (d) } & 0.07 \\ \text { (e) } & 0.22\end{array}$

1.00

$-0.26$

0.07

0.22 (b)

1.00
0.62
-0.54
-0.40

(c)

$$
\begin{array}{r}
1.00 \\
-0.55
\end{array}
$$$$
-0.26
$$

(d)

(e)

93


JBSED

3,1

94

are losing value through the inefficient utilisation of their intellectual capital. The findings revealed that only $8.33 \%$ of the banks attain full capacity in utilising their intellectual capital, while $91.67 \%$ are inefficient. By implication, the findings suggests that majority of banks in Nigeria are expected to seek actionable ways to improve the efficient utilisation of their intellectual capital. Thus, this leadis the study to the enquiry on how intellectual capital efficiency can be improved by the banks. Empirical evidences revealed that bank size and director's shareholding are the dominant factors influencing the intellectual capital efficiency of banks in Nigeria. It was further revealed that the ownership structure and market concentration inhibit the efficient utilisation of commercial banks in Nigeria.

The findings arising from this study raise salient recommendations for policy improvements on banks' performance in Nigeria. First, it is advised that bank regulators should intensify efforts to enforce the disclosure of the banks' intellectual capital in their financial reports. This will considerably drive the attention of the bank managers on the need to effectively identify and manage their intellectual capital resources for improved efficiency and value creation. Secondly, a critical examination of the internal corporate issues within the banking system should be embarked upon as it greatly debars the intellectual capital efficiency of the banks in Nigeria.

Conclusively, this study appears limited because it adopts the exclusion of firms with missing data as a treatment for incomplete data. As such, other researchers may seek to engage other missing data treatment techniques such as the multiple imputation by chained equation (MICE) to replace missing data points. Moreover, this study adopted the DEA nonparametric analysis in evaluating intellectual capital efficiency. Other studies may seek to expand knowledge by adopting other efficiency measures such as the stochastic frontier analysis (SFA) to compare empirical findings. The determinants of intellectual capital efficiency for other sectors and industries are another future research agenda extending the frontiers of knowledge in the intellectual capital efficiency literature.

\section{References}

Adeosun, O.T., Shittu, A.I. and Ugbede, D. (2021), "Disruptive financial innovations: the case of Nigerian micro-entrepreneurs", Journal of Business and Socio-Economic Development, Vol. ahead-of-print No. ahead-of-print, doi: 10.1108/JBSED-01-2021-0006.

Alhassan, A.L. and Asare, N. (2016), "Intellectual capital and bank productivity in emerging markets: evidence from Ghana”, Management Decision, Vol. 54 No. 3, pp. 589-609.

Ali, B.J. and Anwar, G. (2021), "Intellectual capital: a modern model to measure the value creation in a business", International Journal of Engineering, Business and Management, Vol. 5 No. 2, pp. 31-43.

Anifowose, M., Abdulrashid, M.H. and Annuar, H.A. (2018), "Intellectual capital efficiency and corporate book value: evidence from Nigerian economy", Journal of Intellectual Capital, Vol. 19 No. 3, pp. 644-668.

Banker, R.D., Frost, T.S., Abdelhamid, A.M. and Tripathi, M.K. (2021), "Organizational ability and firm performance in transition economies: the case of Egypt", Data Envelopment Analysis Journal, Vol. 5 No. 1, pp. 243-280.

Bayraktaroglu, A.E., Calisir, F. and Baskak, M. (2019), "Intellectual capital and firm performance: an extended VAIC model", Journal of Intellectual Capital, Vol. 20 No. 3, pp. 406-425, doi: 10.1108/JIC12-2017-0184.

Buallay, A., Hamdan, A.M., Reyad, S., Badawi, S. and Madbouly, A. (2020), "The efficiency of GCC banks: the role of intellectual capital”, European Business Review, Vol. 32 No. 3, pp. 1-20, doi: 10.1108/EBR-04-2019-0053.

Cenciarelli, V.C., Greco, G. and Allegrini, M. (2018), "Does intellectual capital help predict bankruptcy? ", Journal of Intellectual Capital, Vol. 19 No. 2, pp. 1-32, doi: 10.1108/JIC-03-2017-0047. 
Charnes, A., Cooper, W.W. and Rhodes, E. (1978), "Measuring the efficiency of decision-making units", European Journal of Operational Research, Vol. 2 No. 6, pp. 429-444.

Choi, B.P. (2019), "Advertising, market concentration, and firm performance on the distribution system”, The International Journal of Business and Finance Research, Vol. 13 No. 2, pp. 21-31.

Feroz, E.H., Kim, S. and Raab, R.L. (2003), "Financial statement analysis: a data envelopment analysis approach", The Journal of the Operational Research Society, Vol. 54 No. 1, pp. 48-58.

Galbraith, J.K. (1969), "The consequences of technology”, Journal of Accountancy, Vol. 127, p. 44.

Hamdan, A. (2018), "Intellectual capital and firm performance: differentiating between accountingbased and market-based performance", International Journal of Islamic and Middle Eastern Finance and Management, Vol. 11 No. 1, pp. 139-151.

Isola, W.A., Adeleye, N.B. and Olohunlana, A.O. (2020), "Boardroom female participation, intellectual capital efficiency and firm performance in developing countries: evidence from Nigeria", Journal of Economics, Finance and Administrative Science, Vol. 25 No. 50, pp. 1-20, doi: 10.1108/JEAFS03-2019-0034.

Isola, W.A., Odekunle, L.A. and Akanni, L.O. (2019), "The impact of intellectual capital on the performance of firms in Nigeria", Unilag Journal of Business, Vol. 5 No. 1, pp. 98-111.

Jamsidy, M., Sofian, S., Bajuri, N.H. and Karchegani, R. (2014), "Mediating role of board of director's functions between intellectual capital components and overall firm performance in Iranian high IC firms", Journal of Applied Sciences, Vol. 14 No. 21, pp. 2750-2766.

Kamukama, N. (2013), "Intellectual capital: firms' hidden source of service quality in the microfinance industry in Uganda", Journal of African Business, Vol. 14 No. 3, pp. 150-161.

Kuo, K.C., Lu, W.M. and Dinh, T.N. (2020), "Firm performance and ownership structure: dynamic network data envelopment analysis approach”, Managerial and Decision Economics, Vol. 41 No. 4, pp. 608-623.

Kweh, Q.L., Lu, W. and Wang, W. (2013), "Dynamic efficiency: intellectual capital in the Chinese nonlife insurance firms", Journal of Knowledge Management, Vol. 18 No. 5, pp. 937-951.

Kweh, Q.L., Lu, W.M., Ting, I.K. and Le, H.T. (2021), "The cubic S-curve relationship between board independence and intellectual capital efficiency: does firm size matter?", Journal of Intellectual Capital, Vol. ahead of print, pp. 1-10, doi: 10.1108/JIC-08-2020-0276.

Lu, W.M., Tung, W.T., Wang, W.K. and Lin, F. (2010), "Capability and efficiency of intellectual capital: the case of fabless companies in Taiwan", Expert Systems with Applications, Vol. 37 No. 1, pp. 546-555.

Meressa, H.A. (2016), "Determinants of intellectual capital performance: empirical evidence from Ethiopian banks", Research Journal of Finance and Accounting, Vol. 7 No. 3, pp. 10-19.

Mohammed, A.A. and Irbo, M.M. (2018), "Intellectual capital and firm performance nexus: evidence from Ethiopian private commercial banks", International Journal of Learning and Intellectual Capital, Vol. 15 No. 3, pp. 189-203.

Mohd-Ariff, H.A., Islam, A. and Zijl, T. (2016), "Intellectual capital and market performance: the case of multinational R\&D firms in the US", The Journal of Developing Countries, Vol. 50 No. 5, pp. 487-495.

Nashier, T. and Gupta, A. (2020), "Ownership concentration and firm performance in India", Global Business Review, pp. 1-18, doi: 10.1177/0972150919894395.

Nitkiewicz, T., Pachura, P. and Reid, N. (2014), "An appraisal of regional intellectual capital performance using data envelopment analysis", Applied Geography, Vol. 53, pp. 246-257.

Ofori-Sasu, D., Abor, J.Y. and Mensah, L. (2019), "Funding structure and technical efficiency: a data envelopment analysis (DEA) approach for banks in Ghana", International Journal of Managerial Finance, Vol. 15 No. 4, pp. 425-443, doi: 10.1108/IJMF-01-2018-0003.

Olunifesi, A.S. and Bontis, N. (2012), "Managing intellectual capital in Nigerian telecommunications companies”, Journal of Intellectual Capital, Vol. 13 No. 2, pp. 262-282.
Intellectual capital efficiency 
JBSED 3,1

Onyekwelu, U.L., Okoh, J.I. and Iyidiobi, F.C. (2017), "Effects of intellectual capital on financial performance of banks in Nigeria", European Journal of Accounting, Auditing and Finance Research, Vol. 5 No. 2, pp. 28-57.

Pulic, A. (2000), "VAIC ${ }^{\mathrm{TM}}$ an accounting tool for IC management", International Journal of Technology Management, Vol. 20 Nos 5-8, pp. 702-714.

Sardo, F. and Serrasqueiro, Z. (2019), "Intellectual capital, growth opportunities, and financial performance in European firms: dynamic panel data analysis", Journal of Intellectual Capital, pp. 1-22, in press, doi: 10.1108/JC-07-2017-0099.

Siti, M., Taliyang, R., Abdul, L. and Mustafa, N.H. (2012), "The determinants of intellectual capital disclosure among Malaysian listed companies", International Journal of Management and Marketing Research, Vol. 4 No. 3, pp. 25-33.

Stewart, T.A. (1997), Intellectual Capital: The New Wealth of Organisations, Double Day, New York, New York.

Tran, N.P. and Vo, D.H. (2020), "Human capital efficiency and firm performance across sectors in an emerging market”, Cogent Business and Management, Vol. 7, pp. 1-15, doi: 10.1080/23311975. 2020.1738832.

Venugopal, D. and Nambi, S.T. (2018), "A data envelopment analysis approach to performance efficiency of intellectual capital - case of Titan company limited", SDMIMD Journal of Management, Vol. 9 No. 2, p. 1.

Vidyarthi, H. (2018), "Dynamics of intellectual capitals and bank efficiency in India", The Service Industries Journal, Vol. 39 No. 1, pp. 1-24, doi: 10.1080/02642069.2018.1435641.

Wang, W.K., Lu, W.M., Kweh, Q.L. and Cheng, I.T. (2014), "Does intellectual capital matter? Assessing the performance of CPA firms based on additive efficiency decomposition DEA", KnowledgeBased Systems, Vol. 65 No. 4, pp. 38-49.

Wu, S., Lin, L.-Y. and Hsu, M.-Y. (2007), "Intellectual capital, dynamic capabilities and innovative performance of organisations", International Journal of Technology Management, Vol. 39 Nos 3/4, pp. 279-295.

Xu, X.L., Li, J., Wu, D. and Zhang, X. (2021), "The intellectual capital efficiency and corporate sustainable growth nexus: comparison from agriculture, tourism and renewable energy sector", Environment, Development and Sustainability, pp. 1-19, in press.

\section{Corresponding author}

Aminat Olayinka Olohunlana can be contacted at: eniayewuyinka@yahoo.com

For instructions on how to order reprints of this article, please visit our website:

www.emeraldgrouppublishing.com/licensing/reprints.htm

Or contact us for further details: permissions@emeraldinsight.com 